\title{
Kazantzakis' Making of God: A Study in Literature and Philosophy
}

\author{
Frederic Will
}

I

Odysseus, on Calypso's isle too long, suddenly found that

The world then seemed a legend, life a passing dream, the soul of man a spiraling smoke that rose in air; in my clear head gods suddenly were born, blazed up, as suddenly were lost, and others rose instead like clouds and fell in rain drops on my sun-scorched mind.

(Odyssey, II, 110-114)

Later on Ithaca, talking to a bronzesmith whom he wanted to make into a disciple:

One night walking along a barbarous coast alone, I mounted toward a temple perched on some high rocks and broke the door down till the walls thundered and groaned, and as I groped in darkness my hands fell with greed on a new god who wove this iron thrust through his belt ... and I flung out my hands unfearing, ripped the belt, and thus the god's sword passed into my mortal hands.

(Odyssey, II, 800-804, 809-810)

At the wedding feast of Telemachus, Odysseus

... pitied youth and felt the unspeakable deep grief

of maids, and like a god spread out his hands and blessed them ...

(Odyssey, II, 1196-1197)

Landing for a while on the way to Helen and Sparta, Oysseus puts on a pretty girl:

The swift mind-reader felt the maiden's fear and joy:

'Yes, you've divined it, lovely lass. I'm a sea-god

who saw you far off from the waves and leapt ashore

so that the thighs of god and man might meet in love.

(Odyssey, III, 499-502)

These random quotations touch many of the ways in which the double voice of Kazantzakis and Odysseus manages to say that man is a god. Discussion of the four passages helps us to see how that double voice operates, and what kind of explicit claims it makes.

The third passage is a familiar literary turn, innocent and minimally meaningful in itself, but here fraught with context. At this point Odysseus is about to cut himself off from Ithaca, from the generation which is replacing him there, and from the system of moral, social, and economic values which dominates now on the island. His freedom, through which he finds the self-transcendence leading to 
divinity, is being formally heralded by the gesture over Telemachus and his bride.

The fourth passage shows Odysseus putting on a girl, and taking her by the ruse of divinity. But is it only a ruse, in the poem's context? That context echoes earlier epic: the hero's going ashore brings us close to Homer's Odysseus (on Ogygia) and to Virgil's Aeneas (at Carthage). There is the same sense of a mighty and dominant figure, his blood mixed with divinity, his possibility, for establishment and creation, unlimited. Naturally enough, Odysseus takes the classical bath of rejuvenation, in waters frothy with godhead; and emerges as transcendently sexy as Homer's Odysseus or as Virgil's Aeneas.

The first and second passages carry us forward into and out beyond the literary. The second is a small vignette, serving a rhetorical purpose in the poem, and concluded by a frank confession of mortality. However it occupies a shadowy cognitive dimension, a realm of obscure reference, which is congenial territory to Kazantzakis (as to most 'Romantic' writers, for whom that realm is a comfortable habitat). What kind of transfer of power took place, when Odysseus ripped away the god's sword and made it his? Did he acquire mana? Did he get the courage to feel himself a peer, in the presence of a god? Or is this entire passage purely a metaphor, a way of naming Odysseus' strength? It is impossible to read Kazantzakis sympathetically and to settle for a view of such passages-and there are many-as purely metaphorical. But it is equally impossible to locate and limit the sense in which they are 'more than' metaphorical. This situation is not unique to Kazantzakis, of course. But it is a characteristic and constant strategy with him.

The first passage serves as a reflection, by Kazantzakis himself, onto the problem just discussed. On the surface and at the center of this passage we see the same wavering between metaphor and actuality. What are these gods that rise up in the mind? Are they 'just words' or are they 'words plus something, outside language, that they mean?' At a deeper level Odysseus and Kazantzakis are discussing the status of this entire poem. They are forcing us to consider what it means to produce, today, an heroic epic poem in which man, represented by a centrally human figure, goes beyond himself into a partial divinity-mixes with gods (Athene, Poseidon), reflects with more than human largeness onto the human situation, aspires to transcend himself. Kazantzakis is not pretending to be more than human himself, as poet. But he is asking us to think about the extremities of literary possibility.

These swift analyses suggest, what is true, that Kazantzakis is very concerned in his Odyssey with man's possibilities of making himself more than man; and that he is quite concerned, though not consistently or systematically, about the role of language and imagination as staters and confirmers of those human possibilities.

When we turn our attention to the massive epic, as a whole, we see both of these concerns reflecting themselves vastly.

Odysseus, and through him Kazantzakis, passes through an immense gamut of experiences; sources of hope, new aspiration, terrible disillusion, ascetic withdrawal from everything human, search for salvation in a final cutting off even 
from his own freedom, a kind of renunciation even of renunciation. There are several large senses in which the character running through these experiences is a bearer of the possibility of becoming a god. The most important sense is this: Odysseus here takes up the whole human condition into himself, and then seems to reach a position, beyond that condition, from which he can look back onto it, can almost take possession of it like its maker. Being a knower and experiencer seems, here, to come close to being a creator; creators of that caliber are partgods.

On the way to that vision Odysseus moves slowly, through painful stages; gradually acquiring a sense of what he is, and of what he means to himself. His stages are marked by visions or dreams. A few will prove the point.

After he leaves Sparta, he goes with his men to Knossos; there, at the harbor, an old man sells him an icon, a seven-headed ivory god. The brutal, lowest head represents the bestial in man; the subsequent heads represent, with nuances, the military, the voluptuous-erotic, the mental, the grievous, the serene, and the soulfully ethereal in man. As Odysseus meditates on this icon he sees that it represents the ascending series of possibilities by which man prepares the godlike to reveal itself in him. Odysseus is both inspired and discouraged:

Ah, my dear God, if only my dark soul could mount

the seven stories step by step and fade in flame,

but I'm devoured by beasts and filled with mud and bran!

(V, 11. 632-34)

The struggle which here he expresses, as internal to himself, he elsewhere views as part of a struggle against God, or of a dialectic by which the god-like and the man-like are played off against each other. Sometimes, as after the destruction of Knossos, Odysseus entertains a vision of God as the great killer of man, and of man as the great resister of god. This vision seems to counteract the vision of the seven-headed icon, but is actually just another version of it. For each turns around the struggle between the god-like and the man-like in man.

The arguments of both these visions are joined in the dream of Odysseus in Egypt, shortly before his visit to the Pharoah.

God like a somber general passed before each friend . . .

drive on, and bear supplies to both battalions then!

$(\mathrm{X}, 11.578,593)$

Fighting both for and against God, in this sense, is like fighting-but often losing -one's way up the ladder of ascension; or like struggling for life in combat with a god, whose insistence on death makes struggle for life meaningful.

The culmination of Odysseus' psychic search to become god, and to let God become him, is Book XIV, in which he ascends a mountain, at the source of the Nile, to spend seven days meditating on his future acts. (The kind of meditation Saint Francis requires of himself, as we shall see, before determining his future acts in Assisi.) His meditation is turbulent, for it fills him with a clear sense of the forces struggling for mastery over him: his animal nature and his spirit, his lust and his purity, and all the atavistic and organic forces constituting the evolutionary process which has made his own thrusting existence possible. Only on the sixth day does he realize that through all this turbulence God is struggling to be released. 
Odysseus ...

leant his chest above the abyss and shuddered deeply

to hear how someone climbed his guts with stubborn groans,

something both beast and man that trod a bloodstained road.

'Who are you, virile voice? Pirate, what is your name?'

'I am that dark beast, God, who mounts eternally.'

(Odyssey, XIV, ll. 1029-34)

To which God replies:

I climb my own dark body, Son, to keep from stifling.

Trees and beasts smother me, and your flesh chokes me, too;

I fight to flee you, not even your soul can hold me now.

Help me, my son, that from your mute and muddy flesh,

from your constraining soul, I might at length fly free.

(Odyssey, XIV, 11. 1041-45)

Odysseus becomes aware of his soul as the wick which God the flame burns, and of his body as the meeting and burning focus of innumerable energies and ancient pressures. What action is possible, after this knowledge? Odysseus decides he must build a city, an Ideal city, to guard god well, both to protect him and free him.

The inner realizations, of Book XIV, include and transcend all of Odysseus' earlier won wisdom, about the presence of god in him; for now he sees that god is working through him, and struggling to be freed through him as a vehicle. He has found an efficient way to affirm both that he is god and that he is not god; that he is immensely powerful and yet painfully finite; that he is torn by struggle and yet is a privileged node of unity in which converge all the divergent forces in the universe-from geological to theological.

After this Odysseus and Kazantzakis begin to turn away from their preoccupation with god. In Book XV Odysseus builds, and prepares to inaugurate, an ideal city in which his vision of a struggling god will be properly embodied. But just before the inauguration an earthquake swallows almost all of the city and its inhabitants, as well as most of Odysseus' comrades. In despair, Odysseus turns suddenly and sharply away from the world, and from his sense that the world is struggling to perfect itself. He only slowly finds his way back into the world, on the way stopping for his last serious attempt to make the idea of god meaningful to him. The humble things of creation seem to intermingle with his own being, as he returns from his state of shock:

Odysseus brimmed with waters, trees, fruit, beasts, and snakes, and all trees, waters, beasts and fruit brimmed with Odysseus.

(Odyssey, XVI, ll. 476-7)

This is not the last time he will feel himself one with the universe, but it is the last time he will come even close to calling that oneness part of god. From this point on, through increasingly allegorical adventures which lead him to death in the Antarctic, Odysseus confines his speculation and experience to forms of humanism. To some degree he has simply changed his vocabulary, wiping the word god out of it. But he has also changed his whole system of accounting metaphorically for the nature of his world. 
When we go back to one of the passages (Odyssey, II, 1l. 110-114) with which we began, we wonder how much we can find out from Kazantzakis, in this epic, about his view of Odysseus' view of god. (A view of which we probably believe, in this case, that it is close to Kazantzakis' own.) Is Kazantzakis trying to tell us that there is a self-deceptive imaginative faculty by which we create god or gods, that man is forever breeding these phantasms? Understanding this question would help us to appreciate the critical ground against which, in this epic, we are to understand Odysseus' particular preoccupation with the godlike.

Are the gods just words? This question seems to haunt Kazantzakis and his Odysseus-who in the middle of his journey turns his back on explanation by gods. In Book IV, just before abducting Helen, Odysseus dreams about the insubstantiality of Zeus, a creature made by man:

the fearful patron of pure friendship, Zeus, came down and stood with flashing flame before the archer's bed.

He foamed with fury at the lips, his thunderbolts twisted and turned like scorpions in his monstrous hands, but the archer yelled: "Unhappy creature of our hearts, I pity your sad doom and harmless thunderbolts.

Should I but bend or move a little, or open my eyes, poor orphaned child born of our fear, you'd fade in airl" He spoke, then raised his lashes slightly, and the god vanished. When day's face in the light shaft whitely shone at last, the wry, fox-minded man thus hailed it with a smile:

"The awesome ancient gods are now but poor bugbears who roam with secret stealth the unguarded brain at night. Welcome, $\mathrm{O}$ light, $\mathrm{O}$ sacred rooster of man's awakening mind!"

(Odyssey, IV, ll. 1256-69)

'Man's awakening mind,' in this case, is free of delusion. Zeus is part of the delusion of unchecked imagination.

The view given to Odysseus, in this dream which is presented as psychic reality, inevitably seems to rise from the narrator of the poem; and as such it sounds like a searching critical statement, from within the epic, about the use made of gods, in that epic, to show alternately how the human can transcend itself, and how puny the human is. It is of course consistent with Odysseus' own 'character,' that he should exist both as doubt and affirmation, and almost at the same time. But in a poem which seemingly fuses narrator with hero, to the degree this romantic poem does, it is impossible to separate the hero's skepticism from the narrator's critical attitude toward his whole construction in language, even when that construction involves god-making. We will see in a few pages that the prologue and epilogue, to the poem, tell us much more. First two more pieces of evidence from the body of the epic.

In Book XVI, after the destruction of his ideal city, Odysseus only gradually returns to his grasp on the world. He dives first into a deep asceticism, pushing away from him all divinity which seems fabricated and merely inherited. He bullies his god.

He dug a small pit with his nails, poured his black blood, 
then called on the great phantom, God, to loom before him, and in a thunderous roar and lightning flash God sprang full-clad in armor, a vain, bearded, swaggering dwarf.

(Odyssey, XVI, ll. 1045-48)

Then he molds god with mudballs and crushes the fantastic shapes in his hands. God took on a thousand shapes 'twitched/ his fat ass like a clown and jigged with bumps and grinds' (ll. 1063-64), bellowed like a 'monstrous bull,' wandered like a mendicant over the earth, begging for pity. But Odysseus takes no pity.

First he uprooted the gay feathers from God's crown who screeched as though he were a peahen plucked alive, then slowly fleeced him of his charms, his bronze gewgaws, his false sword-cuts, his necklaces, his crimson rags, until, stripped bare, God rolled in dirt like a nude hen.

(Odyssey, XVI, ll. 1094-98)

Kazantzakis and Odysseus are here tearing out the foundations of the god-house which had been built earlier in the poem.

In Book XXII (1l. 409-19) Odysseus returns to a more sophisticated theology, while sailing recklessly toward Death at the South Pole. Once again, as in Book IV, the process of god-making is subjected to super-critical scrutiny. God is both a labyrinthine quest deep in our heads'; and 'wide waterways that branch throughout man's heart.' A positive light is shed, here, on the process of which in Book XVI Odysseus wanted to say, that it is one in which we can at least look freshly onto the whole theology-in-language operation of the first half of the epic. That fresh look enables us to see thin parenthesis-marks enclosing, at start and end, all those passages in which Odysseus talks about gods and god-thrusts in man. The thin marks seem to be placed there more by Kazantzakis than by Odysseus; that is, the hand that sketches them seems to move out from the wide narrative of the poem, not that specifically from the hand of Odysseus. The effect of such bracketing is this: it gives the poem's author an additional possibility, for shaping our attitudes toward the significance of god-language in this work. When Kazantzakis stands more indivisibly inside his hero, he temporarily forsakes the possibilities of that useful distance.

The prologue and epilogue to the epic are especially instructive in this regard, for in them Kazantzakis tells us something about his view of the kind of languagemaking involved in such a commitment. Kazantzakis could go no farther than this, in removing himself from any one of his characters, and in standing both within and outside his whole work. It stands to reason that we will here win a glimpse of Kazantzakis' most generalized insights into the god-making, which is so largely language-making, in this epic.

The prologue is an invocation of the spirit of Odysseus, the 'castle-wrecker,' the Captain who is coming. This invocation is justified by Kazantzakis' desire to 'take possession of the world with song.' The Sun is called on for help in remembering and naming all that has happened beneath it. The poet will sing of these things, as they assembled themselves around Odysseus; and in this way the poet will make the whole existence of his hero, in the widest sense, a metaphor for the 
totality of human reality, and for all the points at which that totality includes the god-like. Kazantzakis is telling us about the act, enormous but still single and analyzable, which writing this epic was for him. His position is roughly 'existential'; he attributes to his act the power to constitute existence. In the epilogue he completes this thought. There the Earth calls on its Mother, the Sun, to proclaim a terrible loss:

"Mother, enjoy the food you've cooked, the wine you hold,

Mother, if you've a rose-bed, rest your weary bones,

Mother, I don't want wine to drink or bread to eat-

today I've seen my loved one vanish like a dwindling thought."

(Odyssey, Epilogue, ll. 12-22)

The loved one, Odysseus, is a product of body transformed into mind transformed into air-in short, of imagination. Not only does Odysseus depend on Kazantzakis for the conferring of existence, but his existence cannot survive once the imaginative work, which kept it in being, has come to an end. Obviously we are not far, here, from the question of god-making. The gods within the Odyssey are kept in existence, there, by the same process by which Kazantzakis keeps his entire epic in existence. It is no wonder that the mind of Odysseus, which often lies so near the center of Kazantzakis' narrative, is so often conscious, to itself, of its power to forge (mould, dream, shape, imagine) gods and of its equal power to destroy them.

II

Kazantzakis' preoccupations with gods are always with him, and constantly grow more complicated. $\mathrm{He}$ is in this a man of his and our times. Not only does the term 'god' serve many uses, enable him to express many facets of his own struggle toward self-definition and self-transcendence; he also turns the use of that term into a reason for reflecting onto the term, its use, and its place in the economy of human needs. Though Kazantzakis' own education took him straight to Bergson and Nietzsche, who fired a passion for self-transcendence, it seems also to have taken him into those regions of linguistic analysis, lying between analytical philosophy and existentialism, in which the roots of our lived language are unsparingly exposed.

Saint Francis is that novel of Kazantzakis' in which he addresses himself most obviously to this first set of questions; though not to the second, the more "philosophical,' set. Saint Francis has a lot in common with Odysseus: the same passionate, self-obliterating search; the same sense that the search for God is in some ways the discovery of Him; the same threatened but massive single-mindedness. Does Francis' explicit quest for God, inside the Christian horizon, add anything to our understanding of Kazantzakis' own quest?

Kazantzakis finds new ways of saying, through Francis, that man is intimately entangled in God. At one point Francis remarks:

Brother Leo, open your mind and engrave deeply there what I am about to tell you. The body of man is the bow, God is the archer, and the soul is the arrow. Understand? (P. 206)

God is both in and outside the body. The body contains the soul which in turn is eager to shed the body. Those interrelationships, and distinctions, could not be 
expressed more concisely; nor could the theology of Saint Francis be brought more forcefully into one image. This image reminds us of the Odyssey, yet the tone is different, somehow. Is it that here the notion of goal is more precisely related to the force exerted by God? I think so. The struggle toward heaven gives a tenseness to Saint Francis which was not, and was not supposed to be, at home in the world of the Odyssey.

Though on the whole God is 'outside' of Francis, more than of Odysseus, He is also inside; so that access to Him still involves revealing what is inside one. As always, in Kazantzakis' work, this revealing occurs through self-transcendence rather than through introspection; for becoming what you are not yet is the surest way to become part God. Brother Leo speaks in this book as the voice of moderation. So does the Bishop of Assisi. Francis cuts ruthlessly through their position:

Man stands within the bounds of moderation; God stands outside Or, again:

them. I am heading for God, Bishop, said Francis. (P. 94)

You see, Brother Leo, we are going to go further than we can. (P. 69)

This attack on moderation is always based on some kind of escape from the dominance of the ego, into an 'I-lessness' where God is.

What happiness it is ... what joy not to have any will, not to say

'I,' but to forget who you are, what your name is, and to give

yourself up with confidence to the puffs of God's wind. (P. 321)

Immoderate self-transcendence, toward a freedom from the ego, is an internal view of the process described in the archer, bow, and arrow metaphor. From this internal view, as we are given it often in the novel, it seems that the great man has the power to become God by himself. But that is only a small view of the argument at work here, a smaller view even than it would be of the argument of The Odyssey. The God of Saint Francis (and of Saint Francis in the book) is Kazantzakis' strongest attempt to define parts of a force-being which man cannot make.

That attempt is implicit already in the archer-metaphor, though there too God is brought into intimate relation with the human struggle. In many ways, however, the God of Saint Francis can be viewed as locked in a terrible struggle with the saint, can be viewed as a force which grows more dreadful as man approaches it more closely. (Just as the god of Odysseus destroyed an ideal city which was Odysseus' most advanced effort to establish the self-transcendent among men on earth.) The most terrible example of this occurs on the top of Mount Alvernia, when the angel of God pours through the night onto Francis, and brands him with stigmata. Francis' death results directly from these wounds. But we should not confine our application of this point too closely to single examples. From the time we first see Francis, plunged in dolce vita, to his death in the agony of the body, we learn that his God is forever a countering of his nature, a central violence. Francis gives alternating explanations of this surprising violence. At one time he will blame the body, which by preventing the spirit from understanding and obeying will make God create agonizing tension for spirit. But on the whole, though, we are to understand Francis differently. He refutes the Albigensian 
denier of the body, whom he meets in Rome. He loves innocent creatures which exist simply and purely in their bodies-like birds. We must at the least understand that the body is not a meaningless appendage of the soul. The body is a field of signs. It is a definition of our condition. In that sense there is here a belief in the body which, if it never approaches the body hymns of The Odyssey, is yet far from Albigensian. To that extent, precisely, Francis learns through his body some part of the meaning of God's struggle against him.

\section{III}

The Odyssey: A Modern Sequel is an epic. Saint Francis is a novel. Other novels could have been chosen to elaborate the argument hinted at above; Freedom or Death, Zorba the Greek, or Toda Raba would have brought us to essentially the same points as Saint Francis, which we can regard as representative of Kazantzakis' arguments about god, in his fiction. We noticed that there are wide similarities between the embodied theology of Saint Francis and that of The Odyssey. One salient difference, which has its roots in the nature of literary genre, divides the novel from the epic theology in Kazantzakis. Since he embraces the epic tradition of the isolated hero, who leaves lesser men increasingly behind him, Kazantzakis drives Odysseus beyond all contexts the epic can establish for him; as a consequence Odysseus goes beyond god and replaces god with himself. Kazantzakis' novel-world is more social than this; as by definition (origin plus essential nature) the novel inevitably is. Saint Francis, though heroic, is defined both by the narrator Leo, and by a variety of hostile and sympathetic characters, in terms of whom his heroism assumes its special form. He never replaces god or becomes god; he remains visible in the human context.

My last example of Kazantzakis' literary theology is The Saviors of God: Spiritual Exercises. Here we see Kazantzakis arguing the theology embodied in his imaginative literature. 'Arguing' will never mean, in this writer, strictly disciplined conceptualizing. Here it means sequential thought generated by intuition, perceptions which gather up and direct masses of mastered experience. (We have already noticed the converse of this fact; that imaginative thought in Kazantzakis turns around a firm conceptual axis, the muscle of intelligible material working through, say, The Odyssey or Saint Francis.)

In The Saviors of God Kazantzakis puts his quest clearly before himself:

I have one longing only: to grasp what is hidden behind appearances, to ferret out that mystery which brings me to birth and then kills me, to discover if behind the visible and unceasing stream of the world an invisible and immutable presence is hiding. (p. 51 , no. 4)

At the same time he doubts that we can ever see beneath appearances; man is condemned to remain on the surface of his experience, bound into the cycle of existences which surround him in time and space. This reservation, 'critical' in an epistemological sense, puts around much of the theology, in The Saviors of God, the kind of bracket we earlier found applied to the language-making of The Odyssey. However we hear nothing in The Saviors of God about the inevitable shortcomings of an imaginative work, or of the mind expressing its need in language. In The Saviors of God Kazantzakis is at his most solidary with his text. 
At one point, however, he alludes to the process by which he is choosing the term 'God' to establish his account of existence:

We have seen the highest circle of spiraling powers. We have named this circle God . . . But we have named it God because only this name, for primordial reasons, can stir our hearts profoundly. And this deeply felt emotion is indispensable if we art to touch, body with body, the dread essence beyond logic. (p. 101; 15, 16)

Kazantzakis is trying to find metaphors-God, Abyss, Darkness, Hope are some of the possibilities-to help this 'dread essence' reveal itself.

What is this essence? Why is it dreadful? Finally, what is a 'savior of god?'

We can only define this 'essence' by trying to surround, to besiege and conquer, a vast nameable area at the center of our experience. We are being called from that center.

The cry within me is a call to arms. It shouts: 'I, the cry, am the Lord your God.' I am not an asylum. I am not hope and a home. I am not the Father nor the Son nor the Holy Ghost. I am your General. (p. 67; 9)

The General is ordering us, his 'comrades-in-arms,' to help his struggle upward through us, and through everything else, animal, vegetable, mineral. We are soldiers helping God to become on every front, to realize a totally open becoming which is freedom.

This God is all of us, and all the things that compose our universe-from dung to angels; above all he is the struggle constantly rising through this created world. But-and here we see why He is dreadful-He is a merciless god, a god of force and violence.

God struggles to knead the flesh and brains together in the trough of earth, to cast all this mass of dough into the merciless whirlwind of his rotation and to give it a face-his face.

He struggles in every possible way to make himself manifest, "with seas and with fires, with colors, with wings, with horns, with claws, with constellations and butterflies ...' (p. 95; 53). We, who must struggle militantly to help our General win, cannot view ourselves as members of a happy family of god, for

$\mathrm{He}$ is not the upright head of a family . . . Injustice, Cruelty, Longing, and Hunger are the four steeds that drive his chariot on this rough-hewn earth of ours. (p. 111; 20)

The human members of his family are of every kind; those who serve him best may be evil, or may be good; it is a matter of indifference which they are. Kazantzakis addresses the humans who struggle along with God:

If the road leading you to your liberation is that of disease, of lies, of dishonor, it is then your duty to plunge into disease, into lies, into dishonor, that you may conquer them. You may not otherwise be saved. (p. 117; 59)

We see why this god is dreadful. What is a savior of god? It is one of those struggling created beings who works to help god be complete, and realize himself.

We are one. From the blind worm in the depths of the ocean to the endless arena of the Galaxy, only one person struggles and is imperiled: You. And within your small and earthen breast only one thing struggles and is imperiled. (p. 105; 41) 
The co-strugglers, the soldiers of god, are deeply aware of their unity with the others who struggle. We are aware that god 'cannot be saved unless we save him with our own struggles,' (p. 105), but at the same time we know that our struggles are continually being counteracted and that we are being thrown back. We can feel the resonances of these defeats, can feel them on our own skins. For each time a man closes matter in his heart, or blocks the spirit in his soul, he restricts and restrains god.

Kazantzakis has said something about the essence of god, about why god is dreadful, and about the saving of god. However when we come to questions, like the last one mentioned-to matters of the restraining and blocking of godwe see how little we have learned past mere details. What exactly-or even vaguely-do god and we struggle to become? What does it mean-about that goal of god's struggle-that the evil man and the good man are equally furthering it? Furthermore, what does it mean that nature and man are equally struggling to further it? What is this face of god that god is struggling to put on?

These questions, classical chestnuts of theology, preoccupied Nietzsche and (in a way) Bergson, the two minds whom Kazantzakis found himself best able to use. (Kazantzakis studied with Bergson at the Collège de France, and the élan vital spread from the older to the younger man. Kazantzakis knew Nietzsche's work thoroughly; he translated Thus Spake Zarathustra, and The Birth of Tragedy into Greek.) We can see how directly Kazantzakis has transferred the leading ideas of those men. The large questions he has left untouched are also questions left untouched by those men.

At least two thrusts appear in Kazantzakis' argument which take no impulse from Bergson or Nietzsche. Kazantzakis spoke constantly of god, as we have seen. This continual use defies the Nietzschean conviction that god is dead; this defiance could be only verbal but in fact is substantial, in Kazantzakis. He adds, also, his own insistence on the 'critical problem' (in Kazantzakis' sense)both in general and as it applies to the argument of The Saviors of God. At the beginning he says that

a) the mind of man can perceive appearances only, and never the essence of things; b) and not all appearances but only the appearances of matter; c) and more narrowly still: not even these appearances of matter, but only relationships between them; d) and these relationships are not real and independent of man, for even these are his creations; e) and they are not the only ones humanly possible, but simply the most convenient for his practical and perceptive needs. (p. 49;16)

He casts the greatest doubt on the range of validity of his own argument. He picks up this critical attitude again, in a different mode, at the end of the book.

7 Blessed be all those who hear and rush to free you, Lord, and who say: "Only you and I exist."

8 Blessed be all those who free you and become united with you, Lord, and who say: "You and I are one."

9 And thrice blessed be those who bear on their shoulders and do not buckle under this great, sublime, and terrifying secret:

THAT EVEN THIS ONE DOES NOT EXIST! (p. 131) 
If 'this one does not exist!' then we have to admit that the whole construction of thought and assertion, which constitutes The Saviors of God, is a fiction, even just a jeu d'esprit. To admit that would be to go much farther than Kazantzakis asks us to at the beginning of the book. There he asks us to realize the limitation of human thought; the background of his position sounds 'Buddhist,' as if it derived more from caution about maya than from Kant's Kritik, but it is in any sense just a cautionary epistemology, serving here to limit the claims of the book, to restrict those claims to a limited area of meaningfulness. By the end of the book Kazantzakis is suggesting much more; that in a sentence he can undercut the whole work. It is the supreme stroke of the Romantic master.

Both the beginning and the end of the book conflict with its substance. The substance is presented 'uncritically' as though the claims being made by the theology-parts of which I examined here-are unquestionably valid, or if questionably valid are at least clearly permissible propositions to account for reality. If the assertions made by the body of the book are false it will not be because they exceed what we are able to assert by virtue of our limited equipment; nor will it be because they are projected fictions, games in language. It will be, rather, because those assertions don't tell the truth about the nature and structure of the world we live in. The internal conflict set up, between the body and the limits of The Saviors of God, is damaging. It takes our attention temporarily away from the inadequacy of the substance of that book's body.

IV

Kazantzakis' oeuvre partly confirms the nasty dictum that bad philosophy and good literature walk hand in hand. To consider that oeuvre is therefore to go back into the relationship between art and truth.

First some reflections on the oeuvre-or on those fragments of it which were chosen here. The word 'god' is profusely scattered through The Saviors of God. In that way Kazantzakis wins some free mileage for his argument. He wins for his blind force, struggling toward freedom, the majesty-both rhetorical and intellectual - of traditional theisms. In return for this advantage he does not offer us even the coherent, inhuman god of Bertrand Russell's 'A Free Man's Worship;' a god as lonely, mathematical and inhuman as the planets. (Essentially the god of nineteenth century science, of Huxley or Darwin; and earlier, of Laplace or Lamettrie.) Kazantzakis offers us a messy god: cruel but addicted to freedom, hating matter but at peace with evil, anti-humane but ruthlessly dependent upon the human, independent of what it creates-thus in some sense a genuine creator-yet indistinguishable from what it creates. At the end of the work the author tries to escape responsibility for this theology by a nimble jeu d'esprit. This strategy is a proper possibility (at least) in any philosophy which has built into itself the perception that language is a kind of game-a perception found at the center of, for instance, Wittgenstein's Philosophical Investigations. But it is not proper in a philosophy like that of The Saviors of God, in which the language does nothing to signal to us that it may be a fiction, not continuous with meaningful referents; in which-to be exact-the language does everything possible, with high rhetoric, to persuade us of its meaningfulness. Thus what we find, in The Saviors of God, is a careless and eclectic theology, presented with great 
passion and then snatched from under our noses. It is a wonder that we find this book, as we do, fascinating and impressive.

The explanation of this wonder is simple: even when Kazantzakis writes philosophy (let alone when he writes 'literature') he writes both philosophy and literature; the same text can be read in two ways. (As texts of sacred scripture can be read both 'sacredly' and 'secularly.') As literature his philosophy is fascinating.

His more purely imaginative works do not suffer from the peculiar tension that aches in The Saviors of God. The Odyssey and Saint Francis were the two examples chosen here; neither of them is as philosophically pretentious as The Saviors, though both embody a great deal of philosophical (or theological) argument.

The word 'god' is profusely scattered through both works. I think we saw that in both places Kazantzakis uses the word as he often uses it in The Saviors of God. 'God' is a term which is rarely even defined by context, but which floats in and out serving the valuable functions of defining, nourishing, and providing connotative atmosphere to the situations at hand. We have compiled enough evidence by now. There is no sense in which The Odyssey or Saint Francis escape the charges of being messy theology, which we levelled at The Saviors of God. What is the relation of literature to philosophy, that the former can absorb and even capitalize on the inadequacies of (the presentation of) the latter? In what way can the imitative and immature theology of The Saviors of God be used as a central ingredient in moving and compelling fiction?

T. S. Eliot believed that some 'maturity' of underlying philosophy was required for significant literature. This was a broad notion applied broadly, so that Eliot could get Homer, Lucretius, Dante together as creators of great works, despite their profound philosophical differences. This was Eliot's response to the question: how can literature be great without telling the truth in a great way? It seemed to him at that time that even the essential coherence of truth could be convincingly suggested, or indicated, by literarily embodied experience of sufficient maturity.

Does some such explanation help us to understand the effect and impression of Kazantzakis' theology in The Odyssey and Saint Francis? The vision of the world, inside which the principles of those works move, is caught between theism and heroic humanism, as is usually the case in Kazantzakis.

Odysseus sets off on action by which to find himself, and for a long time god or gods seem to be necessary terms by which to define himself. At one time he seems almost to become a god, at another he struggles against god, at another he destroys god, or god nearly destroys him. The term and the notion of 'god' are here enabling Kazantzakis to intensify the magnitude of Odysseus' search for himself. At one time Odysseus' power is emphasized, at another his weakness. Though the term 'god' is assuming, here, many of the connotations it had in The Saviors of God, it is now part of an argument which makes 'literary' rather than literary-philosophical' claims to being true. Those claims enable us to view the theology of The Odyssey as something like a grounded metaphorical system. And because that grounding has its roots in (at least a version of) old human experience, we can say that an appropriately 'mature philosophy' underlies the 
imaginative argument of The Odyssey, while we do not have to claim for that argument any bearing on truth and falsehood, or at least any such bearing as we ordinarily understand.

In Saint Francis (or The Greek Passion) god is a notion useful, enriching, and at the same time necessary simply to fill out the cast of characters. The use of that notion is in most ways similar to that of The Odyssey, though in one important regard it is different; that Saint Francis does not include his god, in himself, in quite the same way Odysseus does. Saint Francis is looking for god through, and beyond, himself; while Odysseus is looking for himself through god. In either case the notion of god contributes to the imaginative work a rich metaphor both for the human struggle toward self-transcendence, and for the struggle of the universe to incorporate man in its highest values.

The theology-made-literature, which Kazantzakis offers us in his epic poetry and fiction, is in still a further sense removed from the sphere of criticism which applies to the theology, or philosophy, of The Saviors of God. I refer to the ironic device of bracketing (in The Odyssey), or of the slightly dubious narrator, Brother Leo, in Saint Francis. In The Odyssey the author himself suggests that language-making is fiction-making, as well as occasionally giving something like that point of view to Odysseus. These devices emphasize the immunity of imaginative creations to conceptual analysis. (We might say that, at the beginning and end of The Saviors of God, Kazantzakis claims the same freedom from analysis. But the conceptual substance of his argument has gone too far; he can no longer dismiss it, can no longer even bracket it with reservations.)

Do these points confirm the nasty dictum with which we began this section? We can now put that question differently. Does the sufficient maturity, which we are requiring of the philosophy underlying a major imaginative work, serve simply as a vague reference into that philosophia perennis of which we can say that it represents the average range and depth of inherited human experience, though it makes no effort to clear up its own inconsistencies, or organize its implications? We can enlarge the question: does such philosophy nourish the greatness in great literature?

We can only touch a few details of an answer. The loose, wide, self-revising, metaphor-grounded notion of god, which runs through all of Kazantzakis' work, is of enormous literary value; I have pointed this out already. It greatly increases the range and depth of the literary work; criteria for one kind of sustained imaginative vision. What I say for Kazantzakis, here, could be extended to more systematic great poets like Milton and Dante, who also incarnate distinctive visions of the world. But with those two it is different. The theology of the Divine Comedy cannot be tested for truth, any more than Kazantzakis'. Dante's vision of the world, like that of Kazantzakis, is not meant to be put to a verification test. Within itself, however, the theology of the Divine Comedy reveals a joining of human wisdom, conceptual vehicles, and total synthesizing power which together constitute literary coherence and more-something approaching a referential claim. A point comes in Dante where the philosophy nourishing his epic works back through that epic into a kind of truth, that is a kind of proposition about the world. This is true of Milton. He is perhaps the closest of the classic epic 
writers, to us, and yet we feel deeply cut off from his proposition about the world. His literarily embodied theology seems at points to have been imported too directly into his poetry.

Once this kind of conceptual basis, which lends its dignity to literature, finds its way into 'conceptual works'-The Saviors of God, Areopagitica, De Vulgari Eloquentia-it is judged by a different standard; by a cognitive rather than aesthetic standard. (The lines of this distinction are fuzzy but discernible.) Of the many questions following from this axiom I want to conclude with one specific question, which takes us directly back into Kazantzakis' texts. I want to ask whether great imaginative works are in any sense greater if the philosophy they embody is true?

I have tried to describe the aesthetic realm (that in which we find The Odyssey and Saint Francis) as one in which imaginative vision, expressed, is the criterion of value; it being of interest, to the aesthetic value of that expression, that its intelligible content, its intentions, be drawn from spheres of relatively mature, and relatively highly articulated, human experience; but not that they conform to the standards of truth which we apply to the discursive propositions of natural science, or even social science. I am now asking a further question: whether it would make such aesthetic visions greater if they were based on the truth, rather than on fairly haphazard, though seasoned, versions of the philosophia perennis.

The Odyssey makes many assertions about god and gods, about the divine and spiritual; it is our custom either to take these as metaphors or to accept Kazantzakis' various devices for not committing himself through these assertions, to any determinable view of the world. I think the laws of the aesthetic realm provide Kazantzakis with some justification for exactly that non-commitment, as well as that exploitation of inherited human experience, philosophia perennis. But is it indifferent, to our evaluation of his achievement, whether in fact the god-like exists, whether man is only material, etc.? Is it indifferent to us whether Saint Francis' sense, that he is drunk with god, is a delusion, or a legitimate inward account, fictionally realized, of one way man finds himself in his world?

Asked this way the question sounds cruder than it is; even so, it is made askable only by a certain insensitivity to the way in which literature integrates referential truth. From the literary point of view' the integration of truth may well be simply the integration of 'human nature,' truth to which may of course involve truth to falsity, to mistaken accounts of the world-accounts mistaken from the referential viewpoint. However to admit this view of literary (or artistic) truth can go too far, though at first it may seem an irreproachably complete view. The fact is that even literary representation of 'the world as it is' realizes or rises from a referentially based view of truth. To be specific: while Saint Francis-in the novel-may well be truly depicted as a kind of god-drunk man, whether or not God actually (outside the novel) exists, there still remains, in the novel and more deeply in it than its fidelity to human nature, a referential commitment. Here that commitment is unmistakably (despite bracketing by Brother Leo) to the same kind of view of god supported by Francis (in the novel). It is a 'view' that in language it is possible to embody a continuous perception of human reality as 
touched by mystery beyond man, which is paradoxically but cruelly available to man as he struggles to transcend himself. A related view makes up the ultimate referential stratum of The Odyssey. There too the author finally overcomes those devices (like prologue and epilogue) by which he defends himself against unqualified commitment; and he goes on-though still with more distance from his commitment than he had shown in Saint Francis-to affirm a similar embodiment of continuous perception, this time 'adding' the belief that the journey is a literally meaningful metaphor of a way in which man can transcend himself.

The question at stake is whether it can matter, to the quality of works like these, whether their determining philosophical assumptions and assertions are true. That question is finally manageable; for we have reached a level of assertion, in Kazantzakis, at which we can see him taking a real position, a position which could be contradicted, which represents a choice. It is not irrelevant to the value of Saint Francis and The Odyssey that the part of them, which is judgeable by referential standards, is based on a vague and indefensible notion, that man can convert himself into god. The existence of god, through his presence in human experience, is true and truly named here; but that truth, embedded in any amount of philosophia perennis, will not be enough to free either of these works from the complex charge: that if that referential vein in them, which is an authentic component of even their aesthetic status, were more true they, these works, would be more beautiful. 